
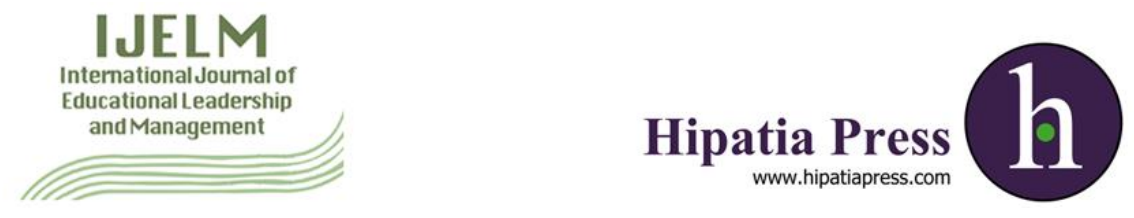

Instructions for authors, subscriptions and further details:

http://ijelm.hipatiapress.com

\title{
Do It Yourself in education: Leadership for learning across physical and virtual borders
}

María Domingo-Coscollola ${ }^{1}$, Judith Arrazola-Carballo², Juana María Sancho-Gil ${ }^{2}$

1) Universitat Internacional de Catalunya. Spain

2) Universitat de Barcelona. Spain

Date of publication: January $16^{\text {th }}, 2016$

Edition period: January 2016-July 2016

To cite this article: Domingo-Coscollola, M., Arrazola-Carballo, J., and Sancho-Gil, J.M. (2016). Do It Yourself in education: Leadership for learning across physical and virtual borders. International Journal of Educational Leadership and Management, 4(1), 5-29. doi: 10.17583/ijelm.2016.1842

To link this article: http://dx.doi.org/10.17583/ijelm.2016.1842

PLEASE SCROLL DOWN FOR ARTICLE

The terms and conditions of use are related to the Open Journal System and

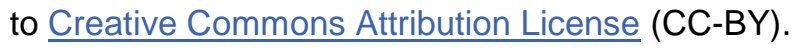




\title{
Do It Yourself in Education: Leadership for Learning across Physical and Virtual Borders
}

María Domingo-Coscollola Universitat Internacional de Catalunya

Juana María Sancho-Gil

Universitat de Barcelona

\author{
Judith Arrazola-Carballo
}

Universitat de Barcelona

\begin{abstract}
Today more than ever, educational institutions need educational leaders who are able to promote profound, substantive and sustainable change. This paper is based on the efforts and results of the first stage of a European project implemented in universities and primary and secondary schools in Spain, Finland and the Czech Republic. The project seeks to explore the changes (and its educational effects) that have occurred in the last decade regarding digital competencies, especially in relation to the emergence of a culture of collaboration that connects youth learning, technology and a Do-it-Yourself (DIY) ethos. To achieve the project's objective, we followed a methodology based on the principles of collaborative action research (CAR). We have analysed the curricula and study plans of the participating institutions in order to explore how and where the project could be applied. We conducted a series of focus groups with teachers, students and parents to discuss notions of DIY learning among the educational communities. Based on these discussions, we began to analyse how each context envisions DIY learning and how it relates to the notion of virtual space. We finished the first stage with the professional development of the teachers, which was aimed at shaping the DIYLabs implementation plan.
\end{abstract}

Keywords: collaborative learning, digital competence, collaborative action research (CAR), agency, self-regulated learning, autonomous learning, leadership for learning 


\section{Do It Yourself en Educación: Liderazgo para el Aprendizaje a través de Fronteras Físicas y Virtuales}

María Domingo-Coscollola Universitat Internacional de Catalunya

Juana María Sancho-Gil Universitat de Barcelona
Judith Arrazola-Carballo

Universitat de Barcelona

\section{Resumen}

Hoy más que nunca, las instituciones educativas necesitan líderes educativos capaces de promover un cambio profundo, sustancial y sostenible. Este artículo se basa en las acciones y los resultados de la primera etapa de un proyecto Europeo implementado en universidades y escuelas de primaria y secundaria de España, Finlandia y la República Checa. El proyecto busca explorar los cambios (y sus efectos educativos) que han ocurrido en la última década con respecto a las competencias digitales, especialmente en relación con la aparición de una cultura de colaboración que conecta el aprendizaje de jóvenes, la tecnología y el ethos del Doit-Yourself (DIY). Para lograr el objetivo del proyecto, hemos seguido una metodología basada en los principios de la investigación-acción colaborativa (CAR). Hemos analizado los currículos y planes de estudio de las instituciones involucradas para explorar cómo y dónde podría aplicarse el proyecto. Hemos llevado a cabo una serie de grupos de discusión con maestros, alumnos y padres para discutir las nociones de aprendizaje del DIY entre las comunidades educativas. Basándonos en estas discusiones empezamos a analizar cómo cada contexto imagina el aprendizaje del DIY y cómo se relaciona con la noción de espacio virtual. Finalizamos la primera etapa con el desarrollo profesional de los profesores destinados a la conformación del plan de implementación de DIYLabs.

Palabras clave: aprendizaje colaborativo, competencia digital, autoría, investigación acción colaborativa, aprendizaje autorregulado, aprendizaje autónomo, liderazgo para el aprendizaje 
I

n a volatile, uncertain, complex and ambiguous (VUCA) world (Johansen, 2007, Sancho \& Hernández, 2011) that is permeated by digital technology and social, political and economic turmoil, educational systems are facing unprecedented challenges (Sancho, 2010). The traditional logic and organisational metaphors that educational institutions understand as privileged knowledge and value transmitters (Debray, 2001) are being confronted by the multiplicity of available environments, both analogical and virtual. Diversified learning and socialization environments have formed apprentices with apparently greater agency and capacity for action and decision, but also with greater perplexity and discontent (Twenge, 2014). In this context, school disaffection is growing and thus contributes to a continuing increase in the number of students who either do not continue their studies beyond compulsory education or do not finish their degrees (Rué, 2014; Wright, 2015).

Today more than ever, educational institutions need a profound, substantive and sustainable change that is able to take into account the complexity and intricate power relations of both the surrounding world and the institutions themselves. Recent research in educational change (Hargreaves \& Shirley, 2009; Sancho \& Alonso, 2012) tells us that sustainable change can only be achieved by involving teachers and students in the decision-making process, as well as when new practices are anchored in the most promising aspects of teachers' professional knowledge. If teachers and students feel that their current knowledge and skills are being dismissed (as so often happens) instead of being recognized as foundations for new development, they will go back to old practices and forget the new skills and resources they have acquired once the project is over.

Educational change posits that leadership -and educational leadership in particular- is not to be found only in the actions of principals and managing bodies, but instead is understood as a general organizational function that is distributed over a network of actors within the institutions (Gronn, 2000; Ogawa \& Bossert, 1995; Spillane, 2006). This distributed leadership is directed at professionally qualified teachers in order to exercise multiple functions of leadership that shape the educational institution as a professional learning community (PLC), making this PLC a community of educational leaders (Krichesky \& Murillo, 2011). In reflecting on leadership for $21^{\text {st }}$ century schools, Hallinger (2009) highlights how the initial theories 
of instructional leadership have evolved into the theory known as "leadership for learning". According to Tintoré (2015), the concept that has surpassed instructional, transformational, and distributed leadership is leadership for learning. Leadership for learning includes distributed leadership. It is also leadership for change that arises from the context of each institution. It is more horizontal and democratic. In addition, it puts emphasis on learning (Tintoré, 2015). In this regard, Robertson (2005) believes that everybody in the institution who is able to learn and to enable those around them to learn is an educational leader. This notion of leadership for learning is what underpins the DIYLab ${ }^{1}$ project, which places teachers and students at the centre of the learning process by recognizing and promoting their agency and responsibility in an autonomous and selfdirected learning process.

This paper is based on the preliminary results of the European project DIYLab - Do It Yourself in Education: Expanding Digital Competence to Foster Student Agency and Collaborative Learning, and it places special emphasis on the ways to promote sound and sustainable change in education by fostering educational leadership. It focuses on the specific objective of identifying the strengths, weaknesses, opportunities, difficulties and challenges in the DIY philosophy that underpins the project, particularly in terms of putting it into practice in the participating educational institutions (universities and primary and secondary school) from Spain, Finland and the Czech Republic. More specifically, we focus on the work done during the first stage of the project (analysis of the context and professional development of teachers).

In this project we do not consider teachers and students as consumers (receptors or repositories) of knowledge and skills that we supposedly transmit to them. We foster learning milieus to enhance teachers' and students' capacities for directing their own learning processes, thinking critically for themselves, taking responsibility for their own positions and taking into account other points of view. We also envision them as producers of content who contribute to blogs and create animations, graphics, and video productions (Ito et al., 2010). This is in line with the proposal of Jenkins, Purushotma, Weigel, Clinton, \& Robison (2009, p. xiii), who suggest shifting "the focus ... from questions of technological access to those of opportunities for participation and the development of cultural competencies and social skills needed for full involvement." 
Teachers and students in the DIYLab project are expected to exercise as leaders in their institutions, so that these institutions can subsequently serve as educational leaders in other organisations and communities at the same time. The DIYLab approach and its educational practice will allow the leadership for learning to advance across physical and virtual borders (Jiménez, Orenes, \& Puente, 2010). Our challenge is to improve learning in educational milieus by improving school leadership (Mulford, 2008; Pont, Nusche, \& Moorman, 2008) and by promoting learning from leadership (Louis, Leithwood, Wahlstrom, \& Anderson, 2010).

This consideration led us to take into account collaborative action research (CAR) as "a participatory, democratic process [...] [that] seeks to bring together action and reflection, theory and practice, in participation with others, in the pursuit of practical solutions to issues of pressing concern" (Reason \& Bradbury, 2001, p. 1). Furthermore, it may be insightful if we were to explore the extent to which the idea of 'disruptive innovation' (Bower \& Christensen, 1995; Christensen, 2012) could be applied in education (Christensen, Horn, \& Johnson, 2010). Disruptive innovation is the unexpected improvement of a product or service on the market; it initially targets a different set of users or consumers and subsequently takes over the existing market (Christensen, 2012).

\section{The DIYLab Project}

The DIYLab project seeks to explore changes in digital competencies over the last decade, as well as their educational effects, especially in relation to the emergence of a culture of collaboration that connects young people's learning, technology and DIY ethos (Kafai \& Peppler, 2011).

Young people's efforts to create and disseminate digital media have been associated with the growing DIY movement (Spencer, 2005). It began in the '90s (McKay, 1998) with arts, crafts and new technologies (Eisenberg \& Buechley, 2008), which are multiple and diverse practices that people engage in (Lankshear \& Knobel, 2010). The DIY culture is now being considered in curriculum contents (Guzzetti, Elliott, \& Welsch, 2010; Kamenetz, 2010), giving educators and students the opportunity to create, share and learn in collaboration.

The DIYLab project also aims to deeply and sustainably transform teaching and learning practices in primary and secondary schools as well as 
in the participating higher education institutions. Its main objective is to promote life-long, life-deep and life-wide learning by expanding students' digital competence, agency, creativity, self-regulation and collaboration. It also seeks to put into practice DIY philosophies (Guzzetti et al., 2010; Lankshear \& Knobel, 2010) by focusing on three main principles: Creating, sharing and learning in collaboration (Domingo-Coscollola, Sánchez-Valero, \& Sancho-Gil, 2014).

The project is divided into three phases:

- Institutional analysis and professional teacher development.

- Implementation.

- Improvement and socio-economic evaluation.

The main aim of the first stage is to identify the best or the most adequate practices in developing key competences, especially the DIYLab learning approach in the participant institutions. The project will develop a 'DIYLabHub' to share the digital objects resulting from the students' learning processes in order to make the experiences sustainable and expandable after the end of the project. Each digital item created from these experiences will address the questions: What have I/we done? How have I/we done it? Why have I/we done it that way? This practice will depend on the use and implementation of different technologies (video editing software, mobile/flexible applications, etc.) and the construction and dissemination of a DIY community (Kafai \& Peppler, 2011) in an open online platform.

Students will become producers of digital objects with experiences that support their critical capacity. Thus, young people will create their "own alternatives to mainstream models of teaching and disseminating information" (Hemphill \& Leskowitz, 2012, p. 2). This is a goal that cannot be achieved by using only a platform or virtual space. Instead, true digital competence means using available devices with pedagogical approaches that connect with youth culture (Buckingham, 2007). With these approaches, it is very important to create, share and develop transdisciplinary and inquirybased projects that guide young people to grow into active and thoughtful learners.

All of this is in line with the importance of acquiring certain skills that have already been highlighted. It also coheres with theories of social constructivism, learning constructionism and connectivism (Kop \& Hill, 2008; Siemens, 2008 among others) as well as the emerging pedagogies that 
are arising from the use of ICT in education. These pedagogies aim to take advantage of the communicative, interactive, creative and innovative potential of a new generation and culture of learning (Adell \& Castañeda, 2012; Aguaded \& Cabero, 2014; Area \& Pessoa, 2012).

\section{Materials and Methods}

In coherence with the perspectives on change and educational leadership underpinning the project, the first stage of the project implied two related actions:

- Identifying which practices were recognized by participant institutions as the best practices for developing key competences, especially digital competence. This required taking into account the need to promote purposeful learning experiences for fostering lifelong, life-wide learning skills and educational leadership.

- Preparing the DIYLab to be implemented in the teaching and learning processes by means of a shared professional teacher development process.

Taking into account the goals of the project, participating educational institutions as a whole (students, parents, teachers, management, etc.) were involved from the early stages of its development. We began with the idea that nothing more than a high level of collaboration and involvement could guarantee the sustainability of the educational concept and the pedagogic approach that supports the project, especially after having been completed. In this regard it was important to understand how the DIY ethos may be successfully incorporated into the school culture, as well as to identify what tensions it might provoke. This means we cannot research only how students and teachers engage with DIY, but also how those experiences affect local understanding of learning, student agency, the role of teachers, and the place for digital tools and online platforms in the school curriculum.

As mentioned above, these actions constituted the first circle of a collaborative action research (CAR) method, which was implemented with the purpose of fostering the process of reflection-action-reflection while also developing a culture of collaboration and discussion. In the following sections we offer a detailed account of the perspective and methods used to collect the needed evidence. 


\section{Curriculum and Analyses of Teaching Plans}

We started by analysing the curricula and teaching plans of all participating institutions. We analysed the national curricula of primary and secondary schools and their local syllabi, particularly in relation to the target years (the 5 th year of primary education and the 3rd year of secondary compulsory education). We also analysed the teaching plans of the participating universities. Overall, seventeen sets of documents were analysed (see Table $1)$.

Table 1

Analysed documents by country

\begin{tabular}{lll}
\hline Educational Institution & National Documents & Local Documents \\
\hline SPAIN & & \\
School & 1 primary, 1 secondary & 1 primary, 1 secondary \\
University & Teaching plans of the following & \\
& undergraduate degrees: & \\
& - Pedagogy & \\
& - Primary School Teacher & \\
& - Infant School Teacher & \\
& - Social Education & \\
&
\end{tabular}

\section{FINLAND}

School

Draft version of new

comprehensive curriculum

(primary/secondary)

\section{CZECH REPUBLIC}

School

University
2 primary, 2 secondary

National curriculum for university teacher education
1 primary, 1 secondary

Proposals of university study programmes

The documents were analysed in order to understand the extent to which national and local educational policy could foster DIY learning in schools 
and universities. To analyse these documents, we took into account all those dimensions related to the notion of learning within the DIY culture:

- Views of autonomous and self-regulated learning.

- Ideas about inquiry-based teaching and learning.

- Approaches to transdisciplinary or interdisciplinary knowledge, links and connections.

- Dimensions of digital competence.

- Concepts of collaborative learning.

- Opportunities and limitations for anchoring the DIYLab program to the curriculum.

Based on these analyses, the consortium developed an in-depth understanding of how each institutional context can support the implementation of DIYLabs. We also identified where possible tensions may arise.

\section{Focus Groups}

The second step was to set up a series of focus groups (Barbour \& Kitzinger, 1999; Kitzinger, 1995). They were carried out in each partner's country. Each institution organized the focus groups by inviting teachers, students and parents (in the case of schools) to participate. They also coordinated the timing, implementation, transcription, analysis and interpretation of the content. The number of participants in each focus group was different, according to the country and the education level (see Table 2).

Table 2

Number of participants in focus groups by country and education level

\begin{tabular}{|c|c|c|c|c|}
\hline Educational Institutions & $\begin{array}{c}\text { Number of } \\
\text { Teachers }\end{array}$ & $\begin{array}{c}\text { Number of } \\
\text { Students }\end{array}$ & $\begin{array}{c}\text { Number of } \\
\text { Parents }\end{array}$ & Total \\
\hline \multicolumn{5}{|l|}{ SPAIN } \\
\hline Primary school & 5 & 6 & 6 & \\
\hline Secondary school & 6 & 6 & 6 & \\
\hline University & 6 from 5 departments & 5 from 6 degrees & & \\
\hline Total country & & & & 46 \\
\hline
\end{tabular}




\begin{tabular}{|c|c|c|c|c|}
\hline Educational Institutions & $\begin{array}{c}\text { Number of } \\
\text { Teachers }\end{array}$ & $\begin{array}{c}\text { Number of } \\
\text { Students }\end{array}$ & $\begin{array}{c}\text { Number of } \\
\text { Parents }\end{array}$ & Total \\
\hline \multicolumn{5}{|l|}{ FINLAND } \\
\hline School (combined) & 8 & 8 & 10 & \\
\hline Total country & & & & 26 \\
\hline \multicolumn{5}{|l|}{ CZECH REPUBLIC } \\
\hline Primary school & 8 & 10 & 5 & \\
\hline Secondary school & 7 & 6 & 6 & \\
\hline University full time & & 9 & & \\
\hline University part time (last term) & & 11 & & \\
\hline University part time (first term) & & 8 & & \\
\hline Total country & & & & 70 \\
\hline Total & & & & 142 \\
\hline
\end{tabular}

The aim of the focus groups was to understand the perspective of the participating educational communities and to study in depth the current opportunities and limitations of the educational institutions involved, specifically in regard to implementing this pedagogical and technological approach.

University researchers and the school coordinators led the discussions in an effort to gain an initial understanding of what dimensions of the DIY ethos were already taking place in the teaching and learning practices, as well as of what resources were available to support them in each educational institution. We focused on how teachers, students and/or parents conceptualize the notion of DIY learning, and this allowed us to garner information that would be useful when designing the DIYLab in each context.

The main ideas of the DIYLab project were presented at the beginning of the meetings, where we dedicated time to discuss the notion and implications of "Do-it-Yourself" and its relationship to teaching and learning. This introduction was followed by comments and an open discussion among the participants in each focus group. The questions posed were open-ended and designed to allow participants to share anecdotes on 
their own learning processes and experiences, as well as to give voice to their personal opinions and considerations. For example, some questions for teachers were:

- When do you think the school fosters or allows the idea of DIY learning that was previously explained? How does it do this? And what tools are used in the process?

- Where else do you believe students are developing these skills? How? And with whom?

- How do you think the school could improve in its manner of supporting this type of learning?

The framework for analysing the contents of the focus groups consisted of these categories:

- Knowledge and evaluation of the notion of DIY.

- Notions of autonomous and self-regulated learning.

- Concepts of interdisciplinary knowledge.

- Dimensions of digital competence.

- Visions of collaborative and problem-based learning.

- How to frame the project by considering the formal aspects of the curriculum.

- Emerging elements that befit each situation.

\section{Professional Teacher Development}

The third step was to implement professional teacher development activities, which we developed in each one of the participant institutions. These activities, from their planning to their development, took place between July and December 2014. The work with the teachers took place during six in situ meetings between October and December 2014. During this time, permanent contact was maintained through a virtual space. The individual dedication of all the participants was at least three hours per week.

The professional development was based on generating dialogic processes by beginning with the background and experiences of the participants, an analysis of the available literature (Guzzetti et al., 2010; Kafai \& Peppler, 2011; Kamenetz, 2010; Lankshear \& Knobel, 2010; McKay, 1998; Spencer, 2005) and practical examples of DIY. In this way we endeavoured to ensure the sustainability of the philosophy of the project.

In the exploratory stage, we considered mainly three questions: 
1. What do we understand by DIY philosophy? Common reflective focus in relation to the DIY philosophy.

2. What happens when we introduce the DIY philosophy into an educational institution? Common reflective focus in relation to the DIY philosophy and education

3. Which technological tools and resources to use? We generated a general vision and also a document that detailed how different software could help to create DIY projects and digital objects (about photography, video, audio and music resources, video games, web production and digital art).

Afterwards, we made decisions about pedagogical specifications to be relocated in each specific context, taking into account the following dimensions: When and where will the DIYLab take place? How will it be integrated into the syllabus? Other questions addressed during the professional teacher development were: What form would the DIY digital objects take? How would they circulate? What kind of educational practice would be involved? As mentioned above, we decided that the DIY digital objects should address the following questions: What have I/we done? How have I/we done it? Why have I/we done it that way? We also negotiated the specifics of the implementation phase in each institution.

The processes undertaken in the different professional development activities allowed all participants to make significant contributions to the shaping of the pedagogical and technological implications of the DIYLab project, as well as to the implementation plan. Also, questions, ideas, proposals and reflections were generated into a context of collaborative learning.

All teachers participating in the project took part. In some cases, other teachers contributed despite not being directly involved, as they were deeply interested in the DIY culture as an educational innovation that intensely engages professional development activities. For example, in the case of the University of Barcelona, this activity was recognised by the Institute of Professional Development for Education, who is responsible for the initial and in-service professional development of university staff. This allowed other faculty who were interested in the topic to attend, in addition to those directly involved in the DIYLab project. 


\section{Main Results of the First Stage}

In this section we present the main results of the project's first steps, specifically in relation to the adopted concept of leadership for learning discussed above. We do so by considering:

- Traces of DIY in curricular agendas.

- Meaning of DIY in focus groups.

- Development and implementation of DIYLab from teachers.

We based our discussion on evidence gathered during the focus groups, on the professional teacher development and also on the contributions made in the virtual space (videos, photos and the text of what was said).

\section{Traces of DIY in Curricular Agendas}

When analysed altogether, the Spanish, Finnish and Czech school curricula reveal three different contexts.

- The Finnish 2016 curriculum demonstrates more affinity with the aims of DIYLab, with more emphasis on transversal approaches to competences and a comprehensive, two-pronged consideration of digital competence (such as multiliteracy and ICT skills). However, this still unimplemented reform sheds little light on what these official policies would look like in practice.

- The Czech context, on the other hand, serves as a reminder that the local school context has a great deal of influence over how the curriculum is introduced and put into practice. Whereas the Czech national curriculum does not share the lexicon and principles of DIY learning, the school itself does, and through local initiatives it has implemented measures that can support the project.

- The Spanish context also reveals a highly motivated school. In contrast to the Czech situation, the national curricula do support specific DIY principles, such as autonomous learning and digital competence, among others. In this way, additional support and incentive are provided to the school.

The analysis also reveals that, in each context, digital competence is of great importance today in all education systems, albeit to different degrees. All three contexts (through "Media Education" in the Czech Republic; "Multiliteracy" and "ICT competence" in Finland; "Information handling 
and digital competence" in Spain) recognize the importance of providing both technical instruction to pupils as well as a transversal space for the complex development and application of these skills.

The DIYLab project acknowledges and supports these issues. By introducing this project in each participating institution, we attempt to develop an effective and sustainable way to support it through the innovative development of transversal, dynamic and collaborative sites for DIY learning.

The school curricula represents a challenge when considering where to extend and deepen more interdisciplinary and integrated projects to foster meaningful learning, curiosity, creativity and learning for understanding. We also found that school communities indicated the lack of a physical space for implementing this project, along with a tight schedule that offered little room for interdisciplinary activities.

All these issues played a key role in the professional development phase, where we struggled against the tradition of our educational culture that tends to tell teachers what they must do and how they must do it.

At the higher educational level, we found an even more complex landscape. On the one hand, it seemed that university staff had more freedom to implement innovation at the classroom level. However, the highly fragmented curricula and the rigidity of the times and schedules can act as limits and challenges to introducing and developing DIYLab. Nevertheless, teachers and students involved in the project see it as a great opportunity to develop it from the perspective of leadership for learning.

\section{Meaning of DIYLab in Focus Groups}

Based on the conversations developed in the focus groups, there were five main issues that dominated the discussions throughout all three countries:

- The idea that students are 'digital natives' is still a pervasive discourse.

- The Internet is an archive of open resources, available for personal use.

- Connectivity is a way of living and learning.

- Virtual spaces, in educational terms, provide a room with infinite differentiation.

- The need of autonomous teaching and learning. 
Now we will offer some highlights from the focus group conversations about DIY in teaching and learning:

- The idea of autonomous learning was familiar to all the participants in the focus groups. However, when discussing "DIY learning", we saw that it is not considered to be exactly the same thing. DIY implies more freedom and choice, and less institutional structure.

- We noted during the focus group discussions that there was little mention of the collaborative dimension of learning, of the "give back to the community" type of ethos that is prominent in the DIY movement. There was a debate on the idea of having total autonomy in one's own learning and the concept of becoming an active and equal citizen within a learning community. Also, there was some discussion about the difference between being in and out of school, as well as between living and learning. But this discussion focussed more on individual than on collaborative learning.

- The notion of community was notably absent when discussing the potentials and perils of bringing more DIY practices into teaching and learning practices. Even if the discussions referred to how young people use technologies to maintain communication and express themselves (young people constantly share and learn with others).

- While doubts about what teaching in a DIYLab could mean were common, teachers also recognized that the model could potentially "free up" their time and allow them to distribute their attention based on who in the classroom needs it more. Teachers recognised the need for a different degree of expertise in order to manage a classroom in this way.

- Relying more on the Internet and student interests forces the educational communities to re-think the importance of core curriculum content. The focus groups discussed whether young people should all be learning the same things, in the same way and at the same time. And if they should not, how can they be assessed?

We were also able to identify possible tensions emerging when thinking about introducing DIY practices into educational institutions:

- What must the role of teachers be when promoting autonomous learning and leadership for learning?

- To what extent do students want more responsibility? 
- How do we shift from the challenges that teachers set for the whole class to the individual challenges of each pupil (and vice versa)?

- What happens to assessment? How should a student's learning be assessed?

\section{Development and Implementation of DIYLab from Teachers}

From the first step in the collaborative action research cycle, we made inferences that were fundamental for the professional development of teachers. This process was intended to correspond to professional development models that teachers were familiar with, which may have resulted in differing strategies in different countries. Nevertheless, the common elements of this process were:

- Based on the exchange between members of the school and the university.

- Linked to classroom practice.

- Taking into account the personal and professional background and interests of all the participants.

- Promoting reflection about the philosophy on which the project is based.

In the professional teacher development, we researched how they engage with DIY, but also how this philosophy affected local understandings of learning, student agency, the role of teachers, and the place for digital tools and online platforms within the educational institution curriculum. Once a basic agreement was reached, an approach was made to some of the main pedagogical principles of the project. We now discuss the first results of applying the DIY philosophy to formal education.

The dimensions of the DIY philosophy in formal education were one of the most debated points in the professional development. Initial questions arose about the characteristics of the DIY philosophy, something fundamental for the implementation of the project. The core doubt identified was: How to articulate an innovative means for promoting open, autonomous and self-regulated learning when proposing the idea to a tightly controlled institution? Examples of the initial questions were: What does the DIY concept in education institution mean for us? How do we move something developed in the sphere of youth culture to our regulated educational institution? How can the DIY philosophy be embodied in our 
educational institution? What are the pedagogical and organisational implications?

The fundamental features of the institutionalisation of the DIY philosophy and its pedagogical application were identified as:

- Creativity (transformation, appropriation, authorship, etc.).

- Collaboration (DIY together).

- Self-regulation (this is linked to problems related to the compartmentalisation of the syllabus and evaluation/self-evaluation).

- Technology (intensive use of technology, which must consider digital technologies that are analogical, artefactual and symbolic).

- Explain and share (interest in explaining to others what I know and sharing it).

These significant features generated new questions:

- What is really done so that we can say we are developing a project based on the DIY philosophy?

- How can all the characteristics of the educational projects be fitted into a formal learning institution or course?

- What is distinctive about the DIY philosophy that can help us promote both the students' and our own learning?

All the above led us to formulate the previously mentioned contradiction. If we try to introduce a learning philosophy (which comes from spontaneous and self-run movements) into institutions that do not usually favour selfregulation, autonomy and agency, it is necessary to develop educational leadership. Will the institution swallow up the DIY philosophy and turn it into a sham? Or will the DIY philosophy be able to transform the educational institution? Thanks to the debate, we could see that the participants had the sufficient resources, arguments and experience to take on and attempt to confront this contradiction:

- Through the creation of new frameworks of action: Learning environments and projects.

- Guaranteeing that the teacher also has a leading role in the project (deactivating the idea of "I command and you do").

- Boosting the capacity of the student to choose what, why and how they want to work.

- Guaranteeing not to work with institution-centred formats. 
- Recognising the need for a process of preparing the students before initiating the projects, understanding that one achieves DIY, not that one comes from it, nor is it imposed.

Technologies (and not only digital technologies) play a leading role in the DIY philosophy. Nevertheless, the fact is that the project is linked to the educational use of technology, and digital competency implies a need to explore the immense possibilities. The teachers took into account the current massive development of digital technologies and the multiplicity of possibilities, applications and resources available, and their generalised feelings were:

- Group work is important as a strategy for advancement.

- Different resources should be combined in order to be able to achieve the objectives.

- There is a need to be up to date but without stress.

- An adaptive process of teachers and students (some moments of disorientation occur).

- The students can also decide on the tools they wish to use, according to what they need to explain.

All the previous findings have played a fundamental role in the implementation of DIYLab at the school and university level, which is currently taking place.

\section{Conclusions}

In this first stage of the project, we learnt about how a transversal project like DIYLab can be integrated into primary and secondary schools as well as higher education. We have explored how educational communities that value autonomous learning (such as the institutions that agreed to participate in this project) conceptualize and work with DIY practices.

We discovered that, although they all offer a great deal of support for autonomous learning and the transversal development of digital competences, the notion of DIY implied going beyond what the educational institutions were already doing. The concept of DIY disturbs the basic understanding of formal learning, such as the core curriculum, the roles of teachers and students, and assessment frameworks. Questions abound when deliberating how, or to what extent DIY deserves a place in educational 
systems. In addressing these questions, our project has provided opportunities for knowledge sharing, creation and analysis.

At this point, the biggest challenge we faced was the task of imagining real, new scenarios, of trying to develop a model that responded to the needs of each context and that also managed to provide a comprehensive and innovative structure for learning institutions. Currently, implementing the DIYLab project requires deconstructing and reconstructing the knowledge of students and teachers, so that we can convert schools and universities into actual learning institutions. More than a decade ago, Senge (2000, p. 276) already noted that "colleges and universities have become the preeminent knowing institutions in a world that increasingly favours learning institutions".

In this context, as evidenced in our project, some practices must be followed for carrying educational practices across physical and virtual borders in a sustainable way, and which also transform teaching and learning practice from leadership into learning. They are:

- Fostering meaningful learning, curiosity, agency, creativity, learning for understanding, collaboration, self-regulation, digital competence, capacity to explain and autonomy. Also, providing students with purposeful learning experiences to foster lifelong, life-deep and lifewide learning skills.

- Considering students as able to direct their own learning process, able to think critically, take responsibility for their own positions, take into account other points of view, as producers of content who can create and disseminate digital media. Giving educators and students the opportunity to create, share and learn in collaboration (active roles on their part).

- Basing activities on the following approach to learning: Learning as a process. Learners as creators of knowledge that is subjective and provisional. We learn best when actively doing and managing our own learning.

- Producing open-source learning materials that are developed by students and teachers in the participating institutions. All learning materials will be placed in the DIYLabHub as an open educational resource to the world.

This project was well received by the participating institutions, which instilled the consortium with the sense that it responded to what the 
educational institutions wanted or sensed they needed. This seems to be the greatest strength of the project. By working with schools that had close ties to research universities and/or a desire to innovate and develop innovative learning practices, a strong foundation was provided for the project. All the members involved agreed with the idea that the "lack of ideal conditions does not serve as an excuse for inaction and conditions do not have to be perfect for change to occur" (Collinson \& Cook, 2013, p. 89).

Atkinson (2011) highlights how implementing the DIY philosophy in the educational institutions serves as a trigger to help find spaces, advance the ideas we already have, and even reach and do things that we did not know or expect. We challenged ourselves and all project participants by:

- Developing a professional atmosphere of learning and cooperation that assist the development of proposals that integrate the three principles of the DIY philosophy: Creating, sharing and learning collaboration.

- Integrating DIY within formal learning contexts, taking into account that this is a type of learning generated in collaborative, informal settings.

Our idea is to make sure that teachers in the educational institutions that participated in the DIYLab project act as educational leaders and that, subsequently, these institutions can become leaders of other organizations at the same time. The DIYLab approach and its educational practice will allow advancement in leadership for learning across physical and virtual borders (Jiménez et al., 2010). Our challenge is to improve learning in educational institutions (Mulford, 2008) as well as to improve leadership for learning (Pont et al., 2008; Robertson, 2005) and learning from leadership (Louis et al., 2010).

\section{Funding}

This project was partially funded by the European Commission; the Lifelong Learning Programme; and the Education, Audiovisual and Culture Executive Agency. 543177-LLP-1-2013-1-ES-KA3MP. [Disclaimer: This paper reflects the views only of the authors, and the Commission cannot be held responsible for any use which may be made of the information contained therein]. 
ESBRINA - Contemporary Subjectivities, Visualities and Educational Environments (2014SGR 0632) http://esbrina.eu

REUNI+D -University Network for Educational Research and Innovation (EDU2010-12194-E): http://reunid.eu

INDAGA-T - Innovative Teaching Group to Foster Inquiry-based Learning. University of Barcelona (GIDCUB-13/087): http://www.ub.edu/indagat

\section{Notes}

${ }^{1}$ DIYLab - Do It Yourself in Education: Expanding Digital Competence to Foster Student Agency and Collaborative Learning.

This project has been funded with support from the European Comission. Lifelong Learning Programme. Education, Audiovisual and Culture Executive Agency. 543177-LLP-1-2013-1ES-KA3MP.

Disclaimer: This document reflects the view only of the authors, and the European Commission cannot be held responsible for any use which may be made of the information contained therein.

\section{References}

Adell, J., \& Castañeda, L. (2012). Tecnologías emergentes ¿pedagogías emergentes? In J. Hernández, M. Penessi, D. Sobrino \& A. Vázquez (Coords.), Tendencias emergentes en educación con TIC (pp. 13-32). Barcelona: Espiral.

Aguaded, I., \& Cabero, J. (2014). Avances y retos en la promoción de la innovación didáctica con las tecnologías emergentes e interactivas. Educar, 30, 67-83. doi: 10.5565/rev/educar.691

Area, M., \& Pessoa, T. (2012). From solid to liquid: New literacies to the cultural changes of web 2.0. Comunicar, 38, 13-20. doi: 10.3916/C382012-02-01

Atkinson, D. (2011). Art, Equity and Learning. Pedagogies against the State. Rotterdam: Sense Publishers. doi: 10.1007/978-94-6091-454-6

Barbour, R., \& Kitzinger, J. (Eds.). (1999). Developing Focus Group Research: Politics, Theory and Practice. London: Sage Publications Ltd.

Bower, J. L., \& Christensen, C. M. (1995). Disruptive technologies: Catching the wave. Harvard Business Review, 73(1), 43. doi: 10.1016/00246301(95)91075-1 
Buckingham, D. (2007). Beyond Technology: Children's Learning in the Age of Digital Culture. Cambridge (UK): Polity Press.

Christensen, C. M. (2012). Disruptive innovation. In A M. Soegaard \& R. F. Dam (Eds.), Encyclopedia of human-computer interaction. Aarhus (Denmark): The Interaction-Dessign.org Foundation. Retrieved from: https://www.interaction-

design.org/encyclopedia/disruptive_innovation.html

Christensen, C. M., Horn, M. B., \& Johnson, C. W. (2010). Disrupting class: How disruptive innovation will change the way the world learns. New York: Mc-Graw Hill Professional.

Collinson, V., \& Cook, T. (2013). Organizational Learning: Leading Innovations. International Journal of Educational Leadership and Management, 1(1), 69-98. doi:10.447/ijelm.2013.03

Debray, R. (2001). Introducción a la mediología. Barcelona: Paidós.

Domingo-Coscollola, M., Sánchez-Valero, J. A., \& Sancho-Gil, J. M. (2014).

Researching with Young People: Collaborating and Educating.

Comunicar, 42, 157-164. doi: 10.3916/C42-2014-15

Eisenberg, M., \& Buechley, L. (2008). Pervasive Fabrication: Making Construction Ubiquitous in Education. Journal of Software, 3(4), 6268. doi: 10.4304/jsw.3.4.62-68

Gronn, P. (2000). Distributed Properties: A New architecture for leadership. Educational Management Administration \& Leadership, 28(3), 317338. doi: 10.1177/0263211X000283006

Guzzetti, B., Elliott, K., \& Welsch, D. (2010). DIY Media in the Classroom: New literacies across content areas. New York: Teachers College Press.

Hallinger, P. (2009). Leadership for 21st century schools: From instructional leadership to leadership for learning. Hong Kong: Hong Kong Institute of Education.

Hargreaves, A., \& Shirley, D. (2009). The fourth way. London: Corwin.

Hemphill, D., \& Leskowitz, S. (2012). DIY activists: Communities of practice, cultural dialogism, and radical knowledge sharing. Adult Education Quarterly XX(X), 1-21 doi: 10.1177/0741713612442803

Ito, M., Baumer, S., Bittanti, M., Boyd, D., Cody, R., Herr-Stephenson, B., ...Tripp, L. (2010). Hanging Out, Messing Around, and Geeking Out: Kids Living and Learning with New Media. Cambridge, MA: MIT Press. 
Jenkins, H., Purushotma, R., Weigel, M., Clinton, K., \& Robison, A. J. (2009). Confronting the Challenges of Participatory Culture. Media Education for the 21 st Century. Cambridge, MA: MIT Press.

Jiménez, A. G., Orenes, P. B., \& Puente, S. N. (2010). An Approach to the Concept of a Virtual Border: Identities and Communication Spaces. Revista Latina de Comunicación Social, 13(65), 214-221. doi: 10.4185/RLCS-65-2010-894-214-221

Johansen, B. (2007). Get There Early: Sensing the Future to Compete in the Present. San Francisco, CA: Berrett-Koehler Publishers, Inc.

Kafai, Y. B., \& Peppler, K. A. (2011). Developing Participatory Competencies in Creative Media Production. Review of Research in Education, 35(1), 89-119. doi: 10.3102/0091732x10383211

Kamenetz, A. (2010). DIY U: Edupunks, edupreneurs, and the coming transformation of higher education. White River Junction, VT: Chelsea Green Pub.

Kitzinger J. (1995). Qualitative Research: Introducing focus groups. British Medical Journal, 311, 299-302. doi: 10.1136/bmj.311.7000.299

Kop, R., \& Hill. A. (2008). Connectivism: Learning theory of the future or vestige of the past? The international Review of Research in Open and Distributed Learning, 9(3). Retrieved from http://www.irrodl.org/index.php/irrodl/article/viewArticle/523/1103\%2 522

Krichesky, G. J., \& Murillo, F. J. (2011). Las Comunidades Profesionales de Aprendizaje. Una estrategia de mejora para una nueva concepción de escuela. REICE. Revista Iberoamericana sobre Calidad, Eficacia y Cambio en Educación, 9(1), 65-83.

Lankshear, C., \& Knobel, M. (2010). DIY Media: A contextual background and some contemporary themes. In C. Knobel \& M. Lankshear, M. (Eds.), DIY media: Creating, sharing and learning with new technologies (pp. 1-21). New York: Peter Lang.

Louis, K. S., Leithwood, K., Wahlstrom, K. L., \& Anderson, S. E. (2010). Learning from leadership: Investigating the links to improved student learning. Minneapolis: University of Minnesota.

McKay, G. (1998). DIY culture: Notes towards an intro. In G. McKay (Ed.), DIY Culture: Party and Protest in Nineties Britain (pp. 1-53). London: Verso. 
Mulford, B. (2008). The leadership challenge: Improving learning in schools. Camberwell (Australia): Australian Council for Educational Research. Retrieved from http://research.acer.edu.au/cgi/viewcontent.cgi?article=1000\&context=a er

Ogawa, R., \& Bossert, S. (1995). Leadership as an organizational quality. Educational Administration Quarterly, 31(2), 224-243. doi: 10.1177/0013161X95031002004

Pont, B., Nusche, D., \& Moorman, H. (2008). Improving school leadership (Vols. 1 \& 2). Brussels: Organisation for Economic Co-operation and Development.

Reason, P., \& Bradbury, H. (Eds.). (2001). Handbook of action research. Participative inquiry and practice. London: Sage.

Robertson, J. (2005). Coaching Leadership. Wellington, NZ: NZCER Press.

Rué, J. (2014). El abandono universitario: Variables, marcos de referencia y políticas de calidad. REDU. Revista de Docencia Universitaria, 12(2), 281-306.

Sancho, J. M. (2010). Digital Technologies and Educational Change. In A. Hargreaves, A. Lieberman, M. Fullan \& D. Hopkins (Eds.), Second International Handbook of Educational Change (pp. 433-444). Springer International Handbooks of Education. doi: 10.1007/978-90-481-26606_26

Sancho, J. M., \& Alonso, C. (Coords.). (2012). La fugacidad de las políticas, la inercia de las prácticas. Barcelona: Octaedro.

Sancho, J. M., \& Hernández, F. (2011). Educar en un mundo volátil, incierto, complejo y ambiguo. Entrevista a David Berliner. Cuadernos de Pedagogía, 410, 44-49.

Senge, P. (2000). The Academy as Learning Community: Contradiction in Terms or Realizable Future? In A. F. Lucas and Associates (Eds.), Leading Academic Change: Essential Roles for Department Chairs (pp. 275-300). San Francisco, CA: Jossey-Bass.

Siemens, G. (2008). Learning and knowing in networks: Changing roles for educators and designers. University of Georgia ITFORUM for Discussion, Paper 105, 1-26. Retrieved from http://it.coe.uga.edu/itforum/Paper105/Siemens.pdf

Spencer, A. (2005). DIY. The rise of lo-fi culture. London: Marion Boyars.

Spillane, J. P. (2006). Distributed leadership. San Francisco, CA: Jossey-Bass. 
Tintoré, M. (2015). Educational Leadership. In S. M. Dahlgaard-Park (Ed.), The SAGE Encyclopedia of Quality and the Service Economy. London: Sage Publications.

Twenge, J. (2014). Generation me. Why today's young Americans are more confident, assertive, entitled and more miserable than ever before. New York: Atria paperback.

Wright, C. P. (2015). Bridging the Gap: Exploring the Need for Better System Representations in Higher Education (Doctoral dissertation, Wright State University. Dayton, $\mathrm{OH}$ ). Retrieved from: https://etd.ohiolink.edu/\%21etd.send_file?accession=wright143281917 $1 \&$ disposition=attachment

María Domingo-Coscollola is Associate Professor of the Faculty of Education at the Universitat Internacional de Catalunya, Spain. http://orcid.org/0000-0002-3449-8156

Esbrina Research Group: http://esbrina.eu/en/home/

REUNI+D Network: http://reunid.eu

Contact Address: mdomingoc@uic.es

Judith Arrazola-Carballo is Research Scholar at Department of Methods of Research and Diagnosis in Education, Faculty of Education, University of Barcelona, Spain.

Esbrina Research Group: http://esbrina.eu/en/home/

REUNI+D Network: http://reunid.eu

Contact Address: judith.arrazola@ub.edu

Juana M. Sancho-Gil is Full Professor of the Department of Didactics and Educational Organisation at the University of Barcelona, Spain. http://orcid.org/0000-0002-2941-5619

Esbrina Research Group: http://esbrina.eu/en/home/

REUNI+D Network: http://reunid.eu

Contact Address: jmsancho@ub.edu 